\title{
INTERNAL AUDITING'S ORGANIZATION AND RELATIONSHIP TO OTHER GOVERNANCE FUNCTIONS
}

\author{
Marc Eulerich ${ }^{*}$, Rainer Lenz ${ }^{* *}$ \\ * Corresponding author, University Duisburg-Essen, Germany \\ Contact details: University Duisburg-Essen, Department Accounting and Finance, Chair for Internal Auditing and Corporate Governance, \\ Lotharstr. 65, 47057 Duisburg, Germany \\ ** Director Corporate Audit Services SAF-HOLLAND GmbH, Germany
}

OPEN

ACCESS

How to cite this paper: Eulerich, M., \& Lenz, R. (2019). Internal auditing's organization and relationship to other governance functions. Corporate

Ownership \& Control, 16(4), 87-102. http://doi.org/10.22495/cocvl6i4art8

Copyright $@ 2019$ The Authors

This work is licensed under a Creative Commons Attribution 4.0 International License (CC BY 4.0).

https://creativecommons.org/licenses/by/ $4.0 /$

ISSN Online: 1810-3057

ISSN Print: 1727-9232

Received: 09.05.2019

Accepted: 21.07 .2019

JEL Classification: M40, M42, G34, G32, M4, G3

DOI: $10.22495 /$ cocvl6i4art8

\begin{abstract}
This study analyzes the integration of the internal audit function (IAF) into the organizational governance structure of nine different organizations and identifies best practices and organizational differences to improve the overall governance quality from the perspective of IAFs. The results of this qualitative study are based on 26 semi-structured interviews, which were conducted with Chief Auditing Executives and Internal Auditors of six listed companies and three organizations from the public/governmental sector. This study highlights factors to improve the relationship between the IAF and other assurance providers, such as the board of directors, the supervisory board in the two-tier-system, the audit committee, risk management or the external auditor. Based on the results, different common practices regarding potential ways of organizing and integrating the internal audit function into organizational governance are identified. The results contribute to the existing literature through a unique inside-view and extend the prior discussion about the benefits and challenges of internal auditors in different organizational (e.g. Roussy, 2015; Roussy \& Perron, 2018). Nevertheless, the typical challenges of qualitative research can be found. All best practices provide an adequate benchmark, and support practitioners as well as scholars to better understand the current best practices of effectively working internal audit function. The study gives additional insights to the growing body of literature about the IAF and uses unique data from practitioners.
\end{abstract}

Keywords: Internal Audit, Internal Auditing Function, Corporate Governance, Organizational Governance, Best Practices

Authors' individual contribution: Conceptualization - M.E.; Methodology - M.E.; Writing - M.E. and R.L.; Investigation - M.E.; Funding - M.E.; Resources - M.E.; Supervision - M.E.

Acknowledgement: The author appreciates the comments of the participants and anonymous reviewers at the 2015 AAA Auditing Section Midyear Meeting. This project was funded by the IIA and a national IIA chapter. Data access may be restricted.

\section{INTRODUCTION}

In today's business environment, running a global organization is a complex endeavor, especially because of the rapidly changing environment and new and unknown risks. Looking at this complexity, it is understandable that management does not have the necessary resources, especially time and skill set, to control every area of the business. It is a common practice to delegate this task to the internal audit function (IAF), to uncover inherent risks and generate additional value through their insights and advice (Behrend \& Eulerich, 2019; Roussy \& Perron, 2018). Although one can easily answer the question of why the IAF should be integrated into the 
governance framework, the questions how this integration should look like is not that obvious. Each organization uses a unique approach to integrate the IAF in its organizational governance, depending on company-specific factors like size, business diversification, international activities or business model.

Due to its unique position as a supporting and assuring instrument for the executive board and the audit committee (AC), the IAF is regularly organized as the main assurance entity, and as an integral part of the whole internal organizational governance structure (De Zwaan et al., 2011; COSO, 2009; Behrend \& Eulerich ,2019). Several studies discuss the changes in the role and the self-perception of internal auditors and the IAF within the company (Gramling et al., 2004; Carcello et al., 2005; Sarens \& De Beelde, 2006; Cohen et al., 2010; Soh \& MartinovBennie, 2011; Eulerich et al., 2013). These studies argue that, especially due to the changing regulatory environment, the IAF is a central part of the corporate governance structure. However, these studies also motivate researchers to further analyze these facts in the context of different geographical or regulatory conditions (Soh \& Martinov-Bennie, 2011; Eulerich \& Ratzinger-Sakel, 2018; Eulerich \& Westhausen, 2018). To achieve an in-depth understanding, alternative research methods in addition to archival or survey data were requested (Roussy, 2015; Goodwin-Stewart \& Kent, 2006; Gramling et al., 2004), and used for specific circumstances and countries. This approach is of particular interest since organizations start to realize that appropriate governance and internal audit infrastructure for each business unit is a crucial factor of the organization's success. Unfortunately, organizations have implemented countless organizational governance approaches, making it difficult to deduce general principles. Based on these aspects, our study analyzes the specific strengths and weaknesses of different approaches how to integrate the IAF and thus, tries to follow three primary research questions:

1. How is the internal audit function integrated into organizations?

2. How is the internal audit function structured?

3. How does the internal audit function report to, and interact with, other governance bodies?

Since prior studies did not focus on the integration of the IAF into the governance framework, we use a unique and previously unavailable data set of nine large multinational organizations to investigate potential differences in organizational governance. Through the use of 26 semi-structured interviews and in-depth analysis of the specific cases was applicable ${ }^{1}$. We analyze the organizational status of IAFs in different profit and non-profit organizations to understand the integration of the IAF in the overall organizational governance framework. Furthermore, we particularly focus on the relationship and the organizational link of the IAF to the main corporate governance actors: the board of directors and the $\mathrm{AC}$ (supervisory board in the two-tier system) as well as the collaboration of the IAF with other internal and external governance actors, like risk management, the compliance function or the external auditor.

\footnotetext{
${ }^{1}$ That nine of the interviewees own the position of a CAE in their
} respective organization.
We tried to understand the company-specific way of organizing the IAF and to identify which best practices could improve the performance and position of the IAF in the overall governance framework. The potential range of best practices starts with IAF processes and working methods and ends with reporting lines or the staffing arrangement. All identified approaches should help to determine an effective way of setting up the IAF and to support the IAF in fulfilling its tasks.

The results allow both, practitioners and scholars, to better understand how IAFs are organized and how the relationship other governance players works. Additionally, the characteristics of different organizational structures with respect to the relationship to the board, the AC, and other government partners can be deduced. Finally, best practices of the IAF are discussed, trying to identify further factors that could influence the efficiency, effectiveness, and the sufficient status of the IAF in its organization. Especially for the scientific discussion, the results offer new insights on the relationship between the IAF and other stakeholders.

The findings from this study contribute to the existing literature on the IAF by adding new insights to previous quantitative research as well as to the very limited qualitative literature. While practitioner studies often exclusively describe best practices, we profile different IAFs with a systematic and structured process in order to derive best practices from this new approach.

The remainder of this paper is structured as follows. After a focused literature review to understand the IAF and its position in the corporate governance context, the research questions will be developed in section two. The third section describes the research methodology and the data set. Section four gives the results for the integration of the IAF into the organizational governance, the reporting lines, and interactions with other government bodies and the internal structure and processes. The fifth section presents the best practices, and section six concludes and discusses the limitations of the research project and gives an outlook on possible future research.

\section{LITERATURE REVIEW OF THE ORGANIZATION OF THE IAF AND RESEARCH QUESTIONS}

\subsection{IAF's organizational integration}

Following the findings of Carcello et al. (2005), an effective IAF is an essential part of a company's success. The IAF helps to improve the quality of corporate governance, internal controls, and risk management (Beasley et al., 2000; Coram et al., 2008; Soh \& Martinov-Bennie, 2011). Furthermore, the IAF's role is perceived as increasingly important (Spira, 2003) in both, profit and non-profit organizations (Arena \& Azzone, 2007). However, Gramling et al. (2004) emphasize that there is a lack of research on organizational factors which influence IAF's work and ultimately, IAF's effectiveness. Furthermore, Spira and Page (2003) conclude, that there is a gap between IAFs' mandated role and their de facto role in corporate governance. This discrepancy is particularly problematic, since different organizations, such as multinational companies, public organizations or non-profit organizations, use 
specific governance structures to align internal auditing's work, which is contradictory to IIA's claim to offer a global framework of IAF's best practices with their standards. Sarens et al. (2012) concrete the function of IIA's standards as follows: "These Standards delineate basic principles that represent the practice of internal auditing as it should be, indicating that these Standards are normative in nature" (p. 192-193). Overall, there seems to be a gap between the normative requirements of IIA's standards and the practical ways how to integrate an IAF into an organization. This gap yields the first research question:

RQ 1: How is the internal audit function integrated into organizations?

\subsection{IAF's structure}

To ensure IAF's quality and effectiveness, the IAF itself has to adjust its structure to the organization of the company. IIA's core principles and standards explicitly formulate in this context, that the IAF has to be aligned "with the strategies, objectives, and risks of the organization" and highlights the relevance of a well-implemented internal structure of the IAF. ${ }^{2}$ Thus, a proper structure of the IAF is a key determinant of the compliance with IIA's standards and a successful quality assessment of the IAF. Once again, the standards offer a normative framework. Nevertheless, the IAF's concrete organization is often a company-specific solution, according to market or competitive requirements. Thus, the structure of the IAF depends on:

- The overall understanding of internal auditing. Optimal alignment of organizational structures and the structure of the IAF.

- Advantages and disadvantages of specific IAF approaches and processes.

Based on IAF's main tasks and objectives, an audit charter should define what the IAF is doing. Afterward, the structure of the IAF should mirror the organization's structure. Of course, this decision is influenced by numerous factors like size, listing status or industry type. Thus, each organization must evaluate the advantages and disadvantages of IAF's structure to determine which form suits best Our second research questions cover these aspects: structured?

$R Q$ 2: How is the internal audit function

\subsection{IAF's reporting lines and interactions}

The literature suggests that IAF's position and function in the corporate governance system is mainly determined by its relationship with other corporate governance stakeholders, such as the board of directors, the supervisory board, the AC or the external auditor (Goodwin, 2003; Ratcliffe, 2009). Especially the interaction with the board of directors and the supervisory board /in the two-tier system) or the AC (in the one-tier system) is identified as a fundamental aspect of IAF's position in the whole governance system (Rezaee \& Lander, 1993; Anderson, 2003; Sarens et al., 2011) and might be influenced by e.g. the use of the IAF as a Management Training Ground (Carcello et al., 2018;

2 e.g. IPPF Core Principles, AS1100, AS1110, AS1111, PS2020 PS2060, PS2400, where AS means "Attribute Standards" and PS means "Performance Standards".
Hoos et al., 2018). Establishing a close collaboration between these governance bodies improves the effectiveness and efficiency of control and audit issues. Therefore, IAF's reporting line is usually directed to the executive board and the AC (Mat Zain et al., 2006).

Besides the executive directors and the $\mathrm{AC}$, the IAF has to collaborate with further assurance providers, like the external auditor, risk management or corporate compliance (Beasley et al., 2008). This collaboration is determined in IIA's standard 2050 "Coordination and Reliance". ${ }^{4}$ Since all internal and external assurance providers have a comparable objective, namely to reduce company's risks, IAF's work can support the efficiency and effectiveness of all other functions (Ge \& McVay, 2005; Krishnan, 2005; Verschoor, 2002). IAF's position between diverse assurance providers is often discussed in the context of the so-called "three-lines-of-defense (TLOD) model". ${ }^{5}$ In sum, the IAF interacts with multiple internal and external stakeholders. These interactions are not standardized and hence they cannot be compared for a different organization. In fact, the knowledge about the concrete structure of this cooperation is scarce. This leads to the third research question.

$R Q$ 3: How does the internal audit function report to, and interact with, other governance bodies?

Based on these three research questions, the next chapter describes the used methodology, including the interview instrument and process, and the given data set and participants of this study.

\section{METHODOLOGY AND DATA SET}

This paper uses a qualitative case study approach following Cohen et al. (2013, 2010); Beasley et al. (2009). Compared to a survey or an experimental setup, qualitative research is extremely beneficial for exploratory research questions and the identification of real-life problems. Furthermore, the qualitative approach helps to evaluate the organizations in more detail and with the flexibility to focus on specific topics that might be relevant for the given research question. Finally, interviews with professionals offer the chance to include unique personal experiences and mindsets and compare the gathered data in an open-ended process. Thus, this method can especially be used for the examination of real-life governance situations. Potential challenges of the qualitative approach arise from the relatively small sample size and potential bias of the interviewees. Nevertheless, since the aim of the study is to understand the complexity of the internal governance organization for practical and scientific purposes, and to map the specific role of the IAF, a qualitative approach seems like the method of choice.

${ }^{3}$ The literature often refers to this fact as the "serving-two-masters problem". As a consequence, there is a latent mistrust on both sides, which potentially yields an insufficient supply of information from management to internal auditing (Abbott et al., 2010).

${ }^{4}$ PS 2050: "The chief audit executive should share information, coordinate activities and consider relying upon the work of other internal and external assurance and consulting service providers to ensure proper coverage and minimize duplication of efforts" 5 The TLOD model summarizes the constituent parts of the enterprise risk management: the internal control system, the risk management and corporate compliance and the IAF (IIA, 2013); ECIIA and FERMA (2010) 


\subsection{Interview instrument}

This study was funded by the IIA and co-funded by the German Institute of Internal Auditors (GIIA), which both supported the design of the questionnaire used. The structure of the interview instrument is based on aspects drawn from the existing literature and the discussion with practitioners as well as academic colleagues. The design was then pretested to two CAEs and two academic colleagues to eliminate possible misconceptions. The instrument includes closed and open-ended questions. Open-ended questions provide the chance to express opinions freely, and closed questions provide a useful framework for answers. Overall we have 15 open and 41 closed questions. Note that all interviewees had the chance to explain their answers to closed questions as well. Based on our three research questions, the interview instrument covered the following:

- General Interview Information (5 questions).

- Company Facts, e.g. number of employees, industry or legal form (6 questions).

- Organizational Governance, organizational structure, legal framework or internationality (10 questions).

- Internal Auditing, e.g. IAF staffing, hierarchy levels or the IAF's role (21 questions).

- Audit Reports, e.g. recipient, control loops or report characteristics (9 questions).

- Further Governance Structures, e.g. governance bodies, importance or relationship (5 questions).

\subsection{Research process}

All information used in the subsequent sections is deduced from the interviews with the CAEs and internal auditors from 9 different organizations. Thereby the contacts were provided directly by the IIA and its national chapters or are from the researchers themselves. Research subjects included leading multinational corporations from industries such as trading, energy, utilities, manufacturing and finance as well as non-profit organizations. It was particularly important that the sample consists of global firms, and firms positioned within one market. Furthermore, research subjects were also selected with respect to a variation in their organizational structure. We have a centralized, decentralized, matrix, or hybrid organizations, and interviewees represent a balanced sample of CAEs and internal auditors. The selection of the participants is comparable to findings of other current qualitative studies about the IAF (e.g. Sarens \& De Beelde, 2006; Mat Zain et al., 2006; Sarens et al., 2009; Soh \& Martinov-Bennie, 2011; Roussy, 2015 and follows a "non-probability sampling" technique since participants are not "statistically representative of the population" (Hair et al., 2007) Since we did not randomly select the companies, potential bias may occur. Nevertheless, because of the sensitive information of this study direct contacts to the interviewees were helpful to create a climate of trust.

Before interviews actually started, all participants were sent a letter of inquiry to ask for their support and contribution in the IIA-research project. Additionally, an overview of the research questions was provided in either case, and it was offered to send the complete interview questionnaire in advance if desired. In the next step, the participating CAEs and internal auditors received a copy of the interview instrument. This approach is regarded to help participants to prepare for the forthcoming interviews and to create a trustful interview atmosphere. The positive effect of giving preparative information to interviewees is e.g. shown by Saunders et al. (2009). They find that this information boosts the credibility and reliability of an investigation since interviewees are allowed to systematically prepare themselves for the interview. This proceeding further gives participants the opportunity to close potential knowledge gaps. This, in turn, leads to a reduction of ineffective, incomplete, and faulty interviews, and results in time savings for further interviews and data analysis.

All interviews took place either in the United States or in Europe between January 2012 and December 2012. The interview length varied between 45 and 180 minutes. In order to gather as many information as possible as well as to ensure the highest possible correctness of all transcriptions, the interviews were conducted by the same two researchers in the headquarters of the respective organizations. While one researcher guided the interviewees through the questionnaire and took very brief notes, the other researcher tried to the transcript as much information as possible. The interviews began with a general description of the study's purpose, and the special instruction that answers from "real life governance situations" help us to identify best practices and the IAF's position within the organizational governance structure. The interviewees were assured that all information they give is anonymous at any time and that the results of the project are for scientific purposes only. The study followed the IIA's guidelines for ethical conduct. That is, participation was voluntary, participants were not required to respond to sensitive questions, and information was tracked anonymously (see above) to protect the interviewees, and to ensure full and free participation.

To avoid a too inflexible answering structure which potentially hampers useful responses (Fontana \& Frey, 2005) the interviews were conducted in a non-directional way (Soh \& MartinovBennie, 2011). In order to provide all participants with a trustful atmosphere in which they feel safe to express themselves freely, we abstained from the use of a digital dictation machine. ${ }^{6}$ For this reason, it was very important to make detailed notes during the interviews in order to produce a rich interview protocol. The interview process in each organization started with an extensive talk to the CAE. Mostly, these initial interviews took around60 minutes. Besides the five basic research topics covered by the interview instrument, the CAEs explained their organization and their understanding of the IAF. After this initial step, IAF staff members from the same audit unit but from different hierarchy levels

${ }^{6}$ The absence of a digital voice recording may lead to a loss of some information, but because of the separation of asking and taking notes the necessary quality schould be guarenteed. 
were interviewed. ${ }^{7}$ By selecting participants from various hierarchy levels, possible biases or faulty self-perceptions of the CAEs can be avoided. Furthermore, it helps to create a full picture of the organizational structure of the IAF and its' relationship to other governance bodies, like the external auditor or the AC. Among the IAF staff, CAEs and internal auditors were selected as the favourable respondents because they provide indepth insights regarding the given questions. After each interview, both interviewers used their notes to prepare a detailed report for each conducted interview. ${ }^{8}$ In the next step, the information was summarized in a protocol and categorized with respect to the relevant interview questions. Finally, the reports were merged and the major findings were discussed within the research team. The finalized drafts of the reports were then sent back to the interviewees for their review and comments. In order to ensure that the reports truthfully capture all relevant information and give a realistic picture of the organizational governance and the position of the IAF, interviewees had the chance to enhance, clarify, and add/delete relevant details, following the process suggested by Soh and Martinov-Bennie (2011). The final reports were then used for the analysis of the relevant categories, topics, and research questions. Every report had an additional "fact sheet" as the first page in order to present the main characteristics of the respective organizations. An open-coding technique that is the process of breaking down, examining, comparing, conceptualizing and categorizing data (Corbin \& Strauss, 1990) was essential to the project and the inductive approach. The analysis phase was divided into different steps in which the qualitative data were coded, ${ }^{9}$ pre-analyzed, divided into subcategories, and compared. The coding was done inductively during the entire process of data analysis within the seven stages: familiarization, reflection, conceptualization, cataloging concepts, re-coding, linking, and re-evaluation (Easterby-Smith et al., 2008).

The actual content analysis followed the instructions of grounded theory by Glaser and Strauss (1967)

The following categories for the codification arose from our research questions and the categories of the interview instrument:

\footnotetext{
${ }^{7}$ In six out of nine organizations interviewees were separated from each other to minimize personal biases, which might occur because of the attendance of the CAE. The remaining interviews with three organizations were conducted with focus groups so that all participants were in the room were conducted with focus groups so that all participants were in the room
at the same time. The potential biases in these cases were assumed to be not at the same time. The potential biases in these cases were assumed to be not
too high because of the trustful atmosphere of the interviews. Of course especially interviews with more than one participant might influence the individual responses. To create a trustful atmosphere for these interviews as well as to reduce the potential pressure of the CAEs on the answers of the internal auditors, the researchers explicitly asked all participating persons about their opinion.

${ }^{8}$ Note that these reports were written by the researchers independently from Note that these reports were
each other at that point of time.

${ }^{9}$ Coding means in this context, that we labeled a single word, a phrase or full-sentence/section with a descriptive code, when the specific data was suitable to one of our interviews questions in the sense of similarity, difference correspondence or causation. In our initial step, we used the question number from our questionnaire as one part of the code and additionally added the number of the relevant research questions as an overall category. If a word/phrase/sentence from the interviewee was relevant for different areas of our questionnaire, of course, we used the dat for different areas. The two researchers from the interview process coded the transcripts individually before the coding results were compared and potential differences intensively discussed.
}

- Focus on RQ 1: Integration of the IAF into the overall organizational governance;

- Focus on RQ 2: Structure and processes of the $I A F$;

- Focus on RQ 3: Reporting to and interaction with other governance bodies.

\subsection{Participants}

As suggested by Beasley et al. (2000) and Soh and Martinov-Bennie (2011), the participants were selected from a wide range of industry sectors in order to avoid a potential industry bias and to gain inherent corporate governance characteristics. The selection was based on personal contacts of the researchers and the help of the national IIA and the IIA research foundation. Additionally, within each selected organization interviewees were chosen from different hierarchical levels of the IAF, which further improves the data quality since the potential bias of e.g. the CAE is reduced. Table 1 (see Appendix A) shows the nine participating organizations. ${ }^{10}$ Six in nine organizations are multinational (including global) listed-companies with average revenue of 57 billion Euro and three national organizations are from the public/governmental sector (from the US and from Germany). Depending on business size and listing, the implementation of a supervisory board and an AC, respectively, is regulated or recommended. The average number of employees is 93,000 with an average number of 123 internal auditors, and an average of 1.57 auditors per 1000 employees. As mentioned above, internal auditors from all hierarchical levels of the IAF, like e.g., CAE, senior auditor, team leader, and junior auditor, were chosen for interviews. This procedure serves our aim to analyze various relationships inside the IAF itself as well as between the IAF and relevant corporate governance stakeholders.

Soh and Martinov-Bennie (2011), (p. 609) state: "the primary aim of employing semi-structured interviews is to gain in-depth insight into the perceptions of the individual interviewees and to develop a greater understanding of corporate governance processes, rather than to draw generalizations from the study". Our study uses 26 interviews to explore individual insights. Since the whole research process was intensively guided and supported by the IIA research foundation and a national IIA and based on the prior scientific and practice literature, the most relevant key topics were identified after the interviews with four organizations and proven in the subsequent cases.

\section{RESULTS}

\subsection{Integration of the IAF into the organizational governance}

Two key ingredients for a successful IAF are objectivity and independence, as pointed out by several position-papers and the IIA standards. The importance of these two factors was underlined by our research project, and our study finds two main

${ }^{10}$ Note that each participant/organization was given a unique code rather than the firm's actual name in order to ensure appropriate anonymity, and to protect the confidential and sensitive information. 
mechanisms which guarantee objectivity and independence within the IAF. First, an internal audit charter and second, subordinating the IAF to the board of directors or the AC.

CAE of the organization no. 6: "The charter ensures that the scope for internal auditors includes aspects like the adherence of national professional standards. Important for the design of the scope is a global validation, a homogeneous transformation, and a continual modification because of the international orientation of the group. This has to take place under the consideration of regulatory governance guidelines to ensure a standardized frame within which auditors operate while doing their day-to-day business".

The IIA standard 1000 defines that "the internal audit charter is a formal document that defines the internal audit activity's purpose, authority, and responsibility. The internal audit charter establishes the internal audit activity's position within the organization, including the nature of the chief audit executive's functional reporting relationship with the board..." Thus, the charter of the IAF clearly differentiates the relevant actors and their respective competencies. Furthermore, all interactions which (negatively) influence the daily business of the IAF are identified, and, if necessary, eliminated. This framework serves as an assurance mechanism for both the internal auditors and the addressees of the audit results. Constant changes within the organization and with respect to its environment are caused by external political as well as regulatory developments and by internal dynamics. The challenges for the IAF which steam from these changes require a constant adoption of the charter and a development of the internal auditors' own skillsets. Thereby, the IAF staff is usually equipped with sufficient knowledge, skills, experience, and professional certifications to meet the requirements of the specific charters. However, in cases where certain skills or knowledge are not available internally, it is possible to acquire outside services to obtain specific, external expertise.

In order to simplify the necessary adoptions, globally standardized charters and auditing standards were established. These standards are often based on the global IIA standards or those from the respective national IIA chapters. Especially for multinational organizations, this type of continuous evaluation of the charter and the governance framework seems to be highly relevant. Summarizing these findings, we can see that the global IIA standards lead to a mostly identical formulation of the IAF charter and only slight modifications because of company-specific factors.

$C A E$ of organization no. 5: "Internal audit is directly subordinated to the management board in order to ensure independence and objectivity to the greatest possible extent".

Although IIA standard 1100 clearly describe that the organizational independence can be achieved, when the CAE reports "to a level within the organization that allows the internal audit activity to fulfill its responsibilities", the practical implementation of this standard is not generalizable for every organization and across the different jurisdictions. Interestingly, our interviews with CAEs from one-tier and the two-tier-governance system gave us the same results. As long as the CAE has the chance to directly interact with the highest functions in the organization, organizational independence can be guaranteed. This means, in the two-tier system it is extremely important to have a direct subordination of the CAE to the C-Level, with CEO, CFO, etc., since those managers lead the company in the day-to-day business. Furthermore, the CAEs present their annual report regularly to the $\mathrm{AC}$ and often send their reports also quarterly to the $\mathrm{AC}$ chairman. Especially in combination with the possibility to have personal meetings with the AC, the CAE has also in critical situations, e.g. where the CEO does not want to discuss a finding with the AC, the chance to give findings to the important governance bodies. Although we cannot directly compare the two-tier board model with the monistic model in the United States or the United Kingdom, the independence is normally guaranteed there, through a direct functional subordination of the CAE to the CEO and a disciplinary subordination to the $\mathrm{AC}$

CAE of the organization no. 7: "From an organizational perspective, internal audit is located in the area of finance. The CAE, therefore, is subordinated to the CFO. However, the CAE reports to the complete executive board. Internal audit is not limited to pure auditing; the tasks of internal audit rather process improvement and auditing-related consulting."

Larger boards with clear separation of functions employ one specific person as a contact for the IAF, while this separation is not needed in smaller boards. In nearly every case, prior to meetings, the CAE coordinates the presented content with the respective board member in charge. That is, conflicts of interest between the board, the IAF, and the AC can be avoided. Furthermore, both a disciplinary and functional subordination of the CAEs to the CEO or CFO or the AC are identified, which leads to typical reporting lines and interactions with other governance bodies.

Since multinational companies have to comply with numerous jurisdictions, a logical approach to solve implementation problems is necessary. One interesting common practice is that the companies always roll-out the strictest rules from one country to all other countries. With this solution, the companies try to protect themselves against law cases based on country-specific laws, since they can argue that they always follow the strictest rules.

$C A E$ of the organization no. 3: "Legal provisions which result from domestic regulatory law as well as international provisions, e.g. those set by the Federal Reserve System (FED), are implemented in the corporation. If the strictness of international regulations exceeds the national or local ones, we always adopt the one which is stricter. This form of implementation is advantageous since it creates a globally consistent regulatory framework within auditors can operate. At the same time, this uniform framework demands specific quality standards from internal auditing”.

\subsection{Internal structure and processes of the IAF}

Besides the implementation of the IAF into the overall organization of the company, IAF's own structure is extremely important for an efficient and effective IAF. The IAFs has a broad range of internal auditors (from 8 to 360), with a relative headcount 
range from 0.2 to 6.19 internal auditors per 1000 employees. The focus of the IAFs is always on audit and consulting, where five out of nine organizations evaluate themselves to have a stronger focus on auditing. Five out of nine organizations use their IAF as a management training ground. Furthermore, we identify in most cases that the structure of the IAF is centralized or decentralized, but always aligned with the organization of the company.

CAE of organization no. 9: "The IAF follows the structure of the organization to which it belongs, and is centralized in the headquarter. Although this centralization represents one of the main characteristics of the IAF's, most of the auditors are present in the headquarter less than 50 percent of their working time".

CAE of organization no. 2: "The success of the audit work depends on the way internal audit is set up in accordance with specific conditions and requirements - that's just the same as we find it in the organization's structure [...]. The organizational structure of internal auditing is determined by the group's core processes, markets served, and the different regions the organization is active in".

CAE of organization no. 4: "The organization of internal audit is oriented towards the value chain of the group and is therefore congruent with the organization of the group".

We did not find any specific differences between countries of origin, industry-type or company type. Thus, aligning the IAF with the organizational structure of the organization practice can be evaluated as a common practice of the profession.

Another possible way to structure the IAF arises from the grade of international activities or prior merges and acquisitions (M\&A). Especially after M\&A-activities, the companies keep the IAFs of their acquired company and integrate them as (regional) hubs in their own IAF. Those hub structures help to align all audit activities from the acquired company with the IAF from the acquirer. Furthermore, regional hubs help the IAF to be as close as possible to important markets or specific cultures. E.g. setting up a hub location with a couple of local internal auditors in China is extremely important when China is or will be the largest market for the company.

Following the organization of the company to align the IAF activities is also the main driver for the definition of the audit universe. E.g. if the company uses a regional organization, the IAF will structure the audit universe based on regional risks. So the different risk areas (e.g. business units, regions, markets, processes, value chain, etc.) are defined based on the overall structure of the organization to ensure an efficient and effective IAF. This is also compliant to IIA standard 2010, which explains that "the chief audit executive must establish a riskbased plan to determine the priorities of the internal audit activity, consistent with the organization's goals".

CAE of organization no. 2: "Overall, our nearly 300 auditors are working at all group levels and fields to anticipate various problems within our global company. This requires a properly planned utilisation of human resources as well as ideal coordination of communication".

CAE of organization no. 6: "Our 100 employees speak more than 20 different languages. Linguistic and cultural diversity is an important factor with respect to the closeness to the corresponding audit objectives, and allows the auditors to deal with their audit work directly during day-to-day business".

An optimal allocation of audit capacity and internal auditors, based on their expertise, has a key role in successful IAF. The optimal allocation of technical, social, and cultural skills is one of the most significant future challenges of internal auditing. Our study finds that the variety of knowledge and the specific qualification of internal auditors is increasing, and our results furthermore indicate that there is a continuous development towards more specialized knowledge, especially in larger IAFs. This fact comes together with the increased complexity of companies, where the need for experts in certain fields of the organization is growing. Especially expertise in the area of IT and data analytics is a required skill set, as well as a good understanding of current business strategies or new product developments. The traditional profile of an internal auditor with a very narrow view of financial statements has become outdated. Modern IAFs are looking for a broad skill and knowledge set, together with specific expertise in relevant areas (e.g. industry knowledge, process knowledge, IT knowledge, etc). As one example, we observed one IAF in our sample, where the team which solely consists of specialists. This can be evaluated as a global trend since the whole profession has to be good enough to audit in a very complex, extremely dynamic and uncertain environment.

Especially because of the diverse activities that the IAFs are performing, the trend to use the IAF as a so-called Management Training Ground (MTG) can be identified in most organizations from our sample. We observe that especially large businesses use the IAF to train/educate/qualify young high-potentials. Internal auditing experience can prepare young professionals for a management career due to the detailed corporate knowledge/expertise, which is gained as an auditor. Although some empirical papers discuss the disadvantages of an IAF that works as a MTG (e.g. Glover et al., 2010; Messier et al., 2011), those organizations which have a MTG emphasize its benefits. This might be a "selfperception" but represents the reality of most IAFs in practice. The interviewees do not see any potential problems of missing objectivity or independence, when using the IAF as a MTG, as long as the MTG-approach follows clear guidelines. Those guidelines define e.g. the length of working time in the IAF before rotating out into a specific position or explain areas where the auditor has to gain knowledge for a future job promotion. This trend is also very important for the development of the whole profession since companies can attract highpotential for the IAF and bring the governance expertise of prior internal auditors into management positions.

CAE of organization no. 5: "The common ground lived here is reflected by the positive reputation of internal audit. It has an important status within the governance structure of the group, and participates in regular and intense exchanges between all governance-bodies involved".

$C A E$ of organization no. 1: "The work of the auditors is significantly made easier by this uniform understanding". 
Talking about the personal aspects of internal auditors brings us to an important finding of the socalled "Common Ground". This common ground is a company-wide understanding of specific values, rules, procedures and processes and helps to coordinate the activities of different employees. The role of this common ground was evaluated as a further factor of successful internal auditing, where every auditor speaks the same language. Especially in IAFs with multiple locations all over the world, a common language and understanding of the objectives of the company or evaluation of risks helps to standardize the reports and most importantly, to allow a comparison of audit results. E.g. if a company with auditors in the United States and auditors in India would receive different results for the same audit object, the value of the audit reports would decrease. Although the common ground was developed and used in different ways, all participants were confident that there is a positive influence of common ground in the long run. Regular meetings of all (worldwide) auditors support the exchange of information and hence influence the common ground positively. This is also from a special interest in the context of knowledge sharing and the development of internal auditors' skill set (see also Seol et al., 2017). Especially after M\&A transactions, the adoption of the given common ground can be challenging. Therefore a "job rotation" is often used to facilitate the integration of a new subsidiary. That is, internal auditors, which worked at the headquarter before, are sent to the subsidiary's audit units for a certain time. This step aims to ensure that the standardized reporting system and audit standards are correctly implemented across the whole group. In response, the former head of the regional audit unit is integrated into an audit team of the IAF in the headquarter, which offers the possibility to learn the procedures and quality features in the group's main IAF. In order to extend the knowledge transfer, the exchange of employees is often performed on lower hierarchy levels within the IAF as well.

In general, the investigated IAFs mainly concentrate on traditional audit activities. A modern understanding of internal auditing, however, implies an additional preventive aspect, which aims to solve potential future problems. Due to its focus on risk and governance issues and since the IAF supports the audited unit, internal auditing often enjoys an excellent reputation within the group, and is perceived rather as a support unit than as the traditional "watchdog". This enhances the sufficient status of the IAF in the organization. The acceptance of the IAF as the main pillar of good corporate governance comes from the ongoing discussion and corporate scandals about weak corporate governance structures in recent years. Therefore, the IAFs are often positioned as a key element connecting to internal governance organs as well as external auditing institutions. This positioning also refers to the relationship towards the board and the AC.

\subsection{Reporting to and interacting with other governance bodies}

IAF's reporting lines have two main directions. On the one hand, internal auditing must ensure a contemporary and sufficient reporting of audit results towards the board of directors respectively the C-Level and the supervisory board. On the other hand, communication is not only directed up-stream but rather there is also an interaction between the IAF and the audited units.

CAE of organization no. 6: "Once a month the CAE meets the chairman of the board at a "standing meeting" to update him to all latest findings. Optionally, he/she has the possibility to receive a short-term appointment within one day in order to inform the chairman about critical incidents".

Vice-CAE of organization no. 8: "The CAE will report to the $\mathrm{AC}$ on a regular basis regarding the adequacy of the department's staff and budget, and with respect to any adjustment made to the audit plan or budget during the course of the year".

While analyzing the collected data, we were able to identify the kind of communication described above in every participating organization. In a first step, we analyzed the reporting towards the responsible member of the board of directors (or the entire board). This communication includes audit reports and regular "personal meetings". The reports usually consist of three different parts. The first part is an executive summary. It includes a short summary of the organization's audit objectives and results and classifies these using a company-specific audit scheme. The dimensions of the audit scheme thereby refer to the design of the internal control framework as well as to companyspecific risk dimensions. In the second part, the current audit findings are documented, and resulting actions are deduced. The concluding third chapter summarizes the results. Additionally, the CAE arranges ad-hoc meetings whenever essential problems occur. This close connection between CAE and CEO or AC has a significant positive impact and reduces the risk of a "serving-two-masters-situation" (Eulerich et al., 2017). However, the intensity of this connection significantly depends on the board of director's appreciation of the IAF. As described in the section about the organizational independence of the IAF, the general structure does not vary from between the one-tier- or the two- tier-board system, as long as direct access to the most important governance bodies is given.

Furthermore, we observed intense communication between the IAF and the audited units in all organizations. These exchanges do not only facilitate the discussion of auditing results but also help to prevent potential future problems by developing adequate measures.

Besides the tasks described in the previous section, the interaction with various internal and external assurance providers is also an essential part of IAF's work. We find a well-developed relationship between internal and external auditors since they both benefit from interacting with each other. The exchange of information helps to transfer knowledge and to avoid duplication of efforts with respect to identical auditing tasks. Additionally, the coordination of internal and external auditors' work yields mutual learning processes. As a result, not only the audit processes are coordinated and optimized but also the underlying expertise is expanded. Furthermore, external auditors are able to improve their audit plans by integrating IAF's information and joint audits offer a chance to take advantage of synergies from coordination. This 
finding is in line with the broad scientific discussion about the reliance and cooperation of both groups.

CAE of organization no. 2: "The RiskGovernance-Compliance (RGC) department is responsible for the elaboration and implementation of a common governance framework, which is mandatory for every employee. This framework describes the tasks and duties every auditor has to fulfill and consequently builds the basis for internal audit's reviews. Within each audit, the IAF examines whether the framework set up by the RGCdepartment is properly followed. The audit results are communicated to the RGC-department in order to identify possible problems and weaknesses in the system affecting the entire group. In the next step, these problems can be solved by improving the framework."

The relationship between the risk management, compliance, and IAF varies strongly depending, on the specific organization. Normally, all functions benefit from using the information from the other departments. But not every organization had collaboration between risk management and the IAF, while the IAF always had direct interaction with the compliance function. Thus, the intensity of collaboration differs with respect to the IAF's selfperception and its tasks within the organizational governance. Furthermore, we find a positive influence on the degree of interaction between the governance bodies if a common ground is provided. The board of directors' responsibility, therefore, is to coordinate the cooperation of different governance bodies.

\section{DISCUSSION OF THE IDENTIFIED PRACTICES}

The main factors which influence IAF's structure with respect to the organizational governance are the governance of the company (e.g. board composition, integration of different governance bodies), the governance understanding (e.g. importance of internal auditing, IAF as partner of board of directors vs. partner of $\mathrm{AC}$ ), the structure of the IAF (e.g. size, professionalism, centralization, skillset), and IAF's relationship to relevant stakeholders (e.g. CEO, CFO, chairman of the AC). The company-specific definition of "good corporate governance" as well as internal auditing's role in this context are also main factors, as well as the general business environment (e.g. industry, size, internationality, regulatory framework). The standards set by the IIA, which are additionally supported by position papers of national IIAs, play a crucial role with respect to an efficient implementation of the IAF. In all cases, we find a significant impact of IIA standards on the internal organization of the IAF.

In order to develop an appropriate way to analyze the different cases, we identify 22 different "attributes" from our questionnaire which are assumed to characterize the organizational structure of an IAF and which were summarized in a fact sheet. ${ }^{11}$

\footnotetext{
${ }^{11}$ Thereby each attribute can be assigned to one of the three main interview topics, and hence to the associated research questions (RQ1 to RQ3). Based on these categories, we identify aggregated values for each attribute. For instance, as a potential answer to RQ 1 organizations can specify their structure as one which either secures objectivity and independence of the IAF or not. Therefore we had the values "secured" or "not secured" for this
}

These fact sheets for every participating organization used the categories from Table 2 (see Appendix A) as well. These fact sheets show the variation in the different attributes for each organization and thus help us to create a unique profile for every company (see Appendix B for a graphical presentation of our results). Merging all profiles helps us to identify similarities and differences between the analyzed organizations based on the 22 different attributes. E.g. if all profile lines form the participants are at one point, common practices can be identified.

So far we have summarized the results of our structured interviews and have outlined how the investigated organizations do integrate their IAF into the organizational governance, do structure their IAF internally, and do report to and interact with other governance bodies. In the following, we will aggregate our findings by identifying common features between the organizations. These results then provide insights on how organizations can position themselves with respect to the three categories, and hence give answers to our normative research questions RQ 1 - RQ 3.

$R Q$ 1: Our interviews clearly suggest that the IAF is always aligned with the company's organizational structure. Furthermore, in order to provide for the high relevance of objectivity and independence according to the IIA standards, both attributes are secured through an adequate integration of the IAF into organizational governance. No distinct common features, and hence no unique practice, can be identified for the attribute "organizational orientation".

$R Q$ 2: No dominant qualification model can be identified. However, common ground is present in all investigated organizations, highlighting the relevance of an IAF structure that facilitates communication and shared values. The number of hierarchy levels, of course, depends on the size of the organization and hence no specific practice can be derived. Our interviews further suggest that IAFs are able to fulfill their purposes with a headcount of not more than 1 internal auditor per 1000 employees in the organization. Thereby the efficient amount of internal auditors, of course, depends on IAF's specific scope of work, the industry in which the organization operates, and other factors. E.g., one of the participating organizations has a headcount of more than 5 internal auditors per 1000 employees (organization 3, profit/financial).

Interestingly, neither for the attribute "audit planning loop" nor "audit planning basis" or "focus of audit activities", consistent results can be identified. Instead, approaches chosen by the organizations are manifold without any apparent pattern. Solely the focus of audit activities seems to be on "consulting and auditing" or "consulting" rather than on "auditing" only.

$R Q$ 3: It is a common practice of the analyzed organizations to report directly in both directions to the CEO and to the audited unit - instead of applying any form of indirect communication. Contrary, indirect reporting to the $\mathrm{AC}$ and external units are common. As a general result, the organizations establish direct reporting lines to both

specific attribute. Table 2 depicts all categories and the relevant values of an IAF.

$$
\text { VIRTUS NTERPRESS }
$$


the CEO and the audited unit and consider the costs and benefits of direct vs. indirect reporting to the AC/external units. Regarding the degree of interaction with other governance bodies, the interviews do not provide consistent results. For the majority of the investigated organizations, the IAF claims that it communicates on request or continuously with risk management, compliance or control. Note that with respect to internal governance bodies "on request" indicates a regular, undetermined process of communication in most case. According to these results, establishing determined or undetermined but first and foremost regular communication channels between the IAF and other internal governance bodies can be identified as a best practice. While the interaction with the AC is often regular as well, our results show that continuous communication is rare. It is obvious that the intensity of communication is mostly driven by the number of supervisory board/AC meetings. Lastly, communication between the IAF and the external auditor/other external governance bodies in general happens on request or in a interval that matches the external reporting dates. Contrary to the communication process with internal governance bodies, "on request" in this case actually mirrors more rare communication intensity. However, the analyzed organizations establish sound communication channels with regular interaction to the external auditor and other external governance bodies.

In the last step, we combine the derived results with insights from the literature (see Section 2) and enrich these considerations with additional information gained during our interviews. In Table 3 (see Appendix A) we outline a set of general practices, which provide a guideline how the IAF can be integrated into the organizational governance, how the IAF can be structured internally, and how the IAF can report to and interact with other governance bodies. A summary of the compared characteristics can be found in Appendix B (Table 4) and is visualized in Figure 1.

\section{CONCLUSION AND OUTLOOK}

This study analyzes the IAF's role within organizational governance structures and its relation to other governance bodies. Based on 26 in-depth, semi-structured interviews with CAEs and internal auditors which reveal the implicit knowledge of the interviewees, our results contribute to the growing literature which highlights the relevance of the IAF as a corporate governance actor. The findings give a first and unique picture of the structure and the positioning of IAFs within the organizational governance of companies. An efficient IAF forms a major source of information and consequently provides significant support for the board members in order to fulfill their supervisory responsibilities. The intensity of collaboration thereby strongly depends the board's valuation of the IAF, but in every sense helps to improve corporate control and audit issues.

Our results show that in most cases the IAF is subordinated to the board of directors (either to the entire board, the CEO or the CFO) and therefore has a direct connection to the highest level of management within an organization. Due to this outstanding organizational integration, internal auditing can be interpreted as a crucial control function. In order to optimally utilize this control function, the internal structure of the IAF, as well as the audit fields, is organized analogously to the corporate organization. A critical discussion of this fact could argue that because of the direct relationship to the executive managers a potential lack of independence and objectivity may arise. But the interviewees confirm especially the organizational status if the IAF is directly subordinated to the CEP/CFO.

This design increases the quality of audit and control units because the audit activities are performed more target-oriented. Furthermore, we find that the level of qualification increases continuously and that the knowledge required is changing from general to specialized. This specialized expertise enables internal auditors and audited units to communicate on the same level and therefore improves the communication as well as the value added. The so-called common ground is identified as another key factor which strongly influences the success of internal auditing. The common ground encourages implicit knowledge exchange and thereby enhances a common corporate feeling. At best, this results in a common corporate governance understanding rather than an exclusive definition for each single corporate governance body. In general, the exchange and the communication between the IAF and other corporate governance actors, especially the board of directors and the AC, are essential for a well-working audit function, which is supposed to create value for the entire business.

Although our study forms a valuable starting point, we are aware of the limitations. We analyze nine organizations, which is a small sample of cases, but a common size for qualitative research. As a consequence, our qualitative results might need a larger quantitative validation. For future research, larger sample size and the use of a survey could aim at this potential drawback, and offer further insights. The organizations are from different countries, different size and profit- and not-forprofit- organizations. Because of this, the findings are not generalizable, and there is a potential sample selection bias13. However, this project was not performed in order to generate generally accepted data, but the results give a first overview of different organizations regarding the organization of an IAF. Our motivation was to observe and analyze the numerous relationships and strategic connections between IAFs, governance institutions, and other organizational instances.

The described limitations of the research project are typical for qualitative research since a qualitative approach cannot claim to generate universal validity or generalizability. For future research, a detailed comparison of organizations with respect to business size, industry or type of organization can be performed only for larger groups of comparable companies. Thereby, it is essential that the new participants are going to be chosen from the typical benchmark of the existing nine organizations. 


\section{REFERENCES}

1. Abbott, L., Parker, S., \& Peters, G. F. (2010). Serving two masters: The association between audit committee internal audit oversight and internal audit activities. Accounting Horizons, 24(1), 1-24. https://doi.org/10.2308/acch.2010.24.1.1

2. Anderson, U. (2003). Research opportunities in internal auditing, Chapter 4: Assurance and consulting services. IIA Research Foundation Report.

3. Arena, M., \& Azzone, G. (2007). Identifying organizational drivers of internal audit effectiveness. International Journal of Auditing, 13(1), 43-60.

4. Beasley, M. S., Carcello, J. V., Hermanson, D. R., \& Lapides, P. D. (2000). Fraudulent financial reporting: Consideration of industry traits and corporate governance mechanisms. Accounting Horizons, 14(4), 441-454. https://doi.org/10.2308/acch.2000.14.4.441

5. Beasley, M. S., Carcello, J. V., Hermanson, D. R., \& Neal, T. (2009). The audit committee oversight process. Contemporary Accounting Research, 26(1), 65-122. https://doi.org/10.1506/car.26.1.3

6. Beasley, M. S., Clune, R., \& Hermanson, D. R. (2008). The impact of enterprise risk management on the internal audit function. Journal of Forensic Accounting, 1-20.

7. Behrend, J., \& Eulerich, M. (2019). The evolution of internal audit research: a bibliometric analysis of published documents (1926-2016). Accounting History Review, 29(1), 103-139. https://doi.org/10.1080/ 21552851.2019.1606721

8. Carcello, J. V., Eulerich, M., Masli, A., \& Wood, D. A. (2018). The value to management of using the internal audit function as a management training ground. Accounting Horizons, 32(2), 121-140. https://doi.org/10.2308/acch-52046

9. Carcello, J. V., Hermanson, D. R., \& Raghunandan, K. (2005). Changes in internal auditing during the time of the major us accounting scandals. International Journal of Auditing, 9(2), 117-127. https://doi.org/10.1111/j.1099-1123.2005.00273.x

10. Cohen, J., Krishnamoorthy, G., \& Wright, A. (2010). Corporate governance in the post Sarbanes Oxley era. Contemporary Accounting Research, 27(3), 751-786.

11. Cohen, J. R., Hayes, C., Krishnamoorthy, G., Monroe, G. S., \& Wright, A. (2013). The effectiveness of SOX regulation: An interview study of corporate directors. Behavioral Research in Accounting, 25(1), 61-87. https://doi.org/10.2308/bria-50245

12. Coram, P., Glavovic, A., Ng, J., \& Woodliff, D. (2008). The moral intensity of reduced audit quality acts. Auditing: A Journal of Practice and Theory, 27(1), 127-149. https://doi.org/10.2308/aud.2008.27.1.127

13. Corbin, J., \& Strauss, A. (1990). Grounded theory research: Procedures, canons, and evaluative criteria. Qualitative Sociology, 13(1), 3-21. https://doi.org/10.1007/BF00988593

14. COSO (2009). Guidance on monitoring internal control systems. Committee of Sponsoring Organizations of the Treadway Commission. Retrieved from https://www.coso.org/Documents/COSO_Guidance_ On_Monitoring_Intro_online1_002.pdf

15. De Zwaan, L., Stewart, J., \& Subratmaniam, N. (2011). Internal audit involvement in enterprise risk management. Managerial Auditing Journal, 26(7), 586-604. https://doi.org/10.1108/02686901111151323

16. Easterby-Smith, M., Thorpe, R., \& Jackson, P. (2008). Management research (3rd. ed.). UK: Sage Publications Ltd

17. ECIIA and FERMA (2010). Monitoring the effectiveness of internal control, internal audit and risk management systems (ECIIA and FERMA Position Paper).

18. Eulerich, M., Henseler, J., \& Kohler, A. G. (2017). The internal audit dilemma - The impact of executive directors versus audit committees on internal auditing work. Managerial Auditing Journal, 32(9), 854-878. https://doi.org/10.1108/MAJ-08-2016-1435

19. Eulerich, M., \& Ratzinger-Sakel, N. (2018). The effects of cultural dimensions on the internal audit function? A worldwide comparison of internal audit characteristics. Corporate Ownership and Control, 15(3-1), 217-229. https://doi.org/10.22495/cocv15i3c1p6

20. Eulerich, M., Theis, J., Velte, P., \& Stiglbauer, M. (2013). Self-perception of the internal audit function within the corporate governance system - Empirical evidence for the European union. Problems and Perspectives in Management, 11(2), 57-72.

21. Eulerich, M., \& Westhausen, H. U. (2018). Cultural differences and similarities between German and Chinese internal audit functions. Journal of Governance and Regulation, 7(2), 57-73. https://doi.org/10.22495/ jgr_v7_i2_p6

22. Fontana, A., \& Frey, J. (2005). The interview: From neutral stance to political involvement. In N.K. Denzin and Y.S. Lincoln (Eds.). The SAGE handbook of qualitative research (pp.695-728).

23. Ge, W., \& McVay, S. (2005). The disclosure of material weaknesses in internal control after the Sarbanes-Oxleyact. Accounting Horizons, 19(3), 137-158. https://doi.org/10.2308/acch.2005.19.3.137

24. Glover, S. M., Prawitt, D. F., \& Wood, D. A. (2010). Internal audit sourcing arrangement and the external auditor's reliance decision. Contemporary Accounting Research, 25(1), 193-213. https://doi.org/10.1506/car.25.1.7

25. Goodwin, J. (2003). The relationship between the audit committee and the internal audit function: Evidence from Australia and New Zealand. International Journal of Auditing, 7(3), 263-278. https://doi.org/10.1046/j.1099-1123.2003.00074.x

26. Goodwin-Stewart, J., \& Kent, P. (2006). The use of internal audit by Australian companies. Managerial Auditing Journal, 21(1), 81-101. https://doi.org/10.1108/02686900610634775

27. Gramling, A., Maletta, A., Schneider, A., \& Church, B. (2004). The role of the internal audit function in corporate governance: A synthesis of the extant internal auditing literature and directions for future research. Journal of Accounting Literature, 23, 194-244.

28. Hair, J. F., Money, A. H., Samouel, P., \& Page, M. (2007). Research methods for business (1st ed.). US: John Wiley and Sons. 
29. Hoos, F., Messier, W. F., Smith, J. L., \& Tandy, P. R. (2018). An experimental investigation of the interaction effect of management training ground and reporting lines on internal auditors' objectivity. International Journal of Auditing, 22(2), 150-163.

30. IIA (2013). The three lines of defense in effective risk management and control. The Institute of Internal Auditors. Retrieved from https://na.theiia.org/standards-guidance/Public\%20Documents /PP\%20The\% 20Three\%20Lines\%20of\%20Defense\%20in\%20Effective\%20Risk\%20Management\%20and\%20Control.pdf

31. Krishnan, J. (2005). Audit committee quality and internal control: An empirical analysis. The Accounting Review, 80(2), 649-675. https://doi.org/10.2308/accr.2005.80.2.649

32. Mat Zain, M., Subramaniam, N., \& Stewart, J. (2006). Internal auditor's assessment of their contribution to financial statement audits. The relation with audit committee and internal audit function characteristics. International Journal of Auditing, 10(1), 1-18. https://doi.org/10.1111/j.1099-1123.2006.00306.x

33. Messier, W. J., Reynolds, J. K., Simon, C. A., \& Wood, D. A. (2011). The effect of using the internal audit function as a management training ground on the external auditor's reliance decision. The Accounting Review, 89(6), 2131-2154. https://doi.org/10.2308/accr-10136

34. Ratcliffe, P. (2009). How to maximise the value of internal audit at board level. In Annual Government Heads of Internal Audit Conference, Speaker notes.

35. Rezaee, Z., \& Lander, G. (1993). The internal auditor's relationship with the audit committee. Managerial Auditing Journal, 8(3), 35-40. https://doi.org/10.1108/02686909310036269

36. Roussy, M. (2015). Welcome to the day-to-day of internal auditors: How do they cope with conflicts? Auditing, 34(2), 237-264. https://doi.org/10.2308/ajpt-50904

37. Roussy, M., \& Perron, A. (2018). New perspectives in internal audit research: A structured literature review. Accounting Perspectives, 17(3), 345-385. https://doi.org/10.1111/1911-3838.12180

38. Sarens, G., Abdolmohammadi, M. J., \& Lenz, R. (2012). Factors associated with the internal audit function's role in corporate governance. Journal of Applied Accounting Research, 13(2), 191-204. https://doi.org/ $10.1108 / 09675421211254876$

39. Sarens, G., \& De Beelde, I. (2006). The relationship between internal audit and senior management: an analysis of expectations and perceptions. International Journal of Auditing, 10(3), 219-241. https://doi.org/ 10.1111/j.1099-1123.2006.00351.x

40. Sarens, G., De Beelde, I., \& P., E. (2009). Internal audit: the expert in providing comfort to the audit committee the case of risk management and internal control. British Accounting Review, 41(2), 90-106.

41. Sarens, G., Abdolmohammadi, M. J., \& Lenz, R. (2011). Factors associated with the internal audit function's role in corporate governance. Journal of Applied Accounting Research, 13(2), 191-204. https://doi.org/10.1108/ 09675421211254876

42. Saunders, M., Lewis, P., \& Thornhill, A. (2009). Research methods for business students (5th ed.). Italy: Pearson Education Limited.

43. Seol, I., Sarkis, J., \& Wang, R. (2017). A cross-cultural comparative study of internal auditor skills: UK vs. Korea. Journal of Applied Accounting Research, 18(3), 341-355. https://doi.org/10.1108/JAAR-09-2014-0100

44. Soh, D., \& Martinov-Bennie, N. (2011). The internal audit function: Perceptions of internal audit roles, effectiveness, and evaluation. Managerial Auditing Journal, 26(7), 605-622. https://doi.org/10.1108/ 02686901111151332

45. Spira, L. (2003). Risk management: The reinvention of internal control and the changing role of internal audit. Accounting, Auditing \& Accountability Journal, 16(4), 640-661. https://doi.org/10.1108/09513570310492335

46. Verschoor, C. (2002). Reflections on the audit committee's role. The Internal Auditor, 59(2), 26-35. 


\section{APPENDIX A}

Table 1. Characteristics of the participants

\begin{tabular}{|c|c|c|c|c|c|c|c|c|c|}
\hline Criteria & 1 & 2 & 3 & 4 & 5 & 6 & 7 & 8 & 9 \\
\hline Industry Sector & $\begin{array}{l}\text { Public } \\
\text { Service }\end{array}$ & Industry 1 & Financial & Supply & Industry 2 & Trade & $\begin{array}{l}\text { Industrial } \\
\text { Services }\end{array}$ & Education & Transportation \\
\hline Revenues in Mio. & n.a. & 120,000 & n.a. & 50,000 & 50,000 & 65,000 & 1,000 & n.a. & 6,500 \\
\hline Employees & 115,000 & 95,000 & 60,000 & 72,000 & 180,000 & 280,000 & 10,000 & 15,000 & 63,000 \\
\hline IA-Empl. & 220 & \begin{tabular}{|c|}
$80(\mathrm{HQ})$, \\
220 \\
(subsidiaries) \\
\end{tabular} & 360 & 54 & 36 & 100 & 8 & 18 & 85 \\
\hline $\begin{array}{l}\text { IA-Empl. Per } \\
\text { 1.000 Empl. }\end{array}$ & 1.90 & 0.82 & 6.19 & 0.75 & 0.20 & 0.36 & 0.80 & 0.78 & 1.3 \\
\hline $\begin{array}{l}\text { Audit vs. } \\
\text { Consulting } \\
\text { Focus of the IAF }\end{array}$ & $\begin{array}{l}\text { more } \\
\text { audit }\end{array}$ & $50 / 50$ & $\begin{array}{l}\text { more } \\
\text { audit }\end{array}$ & $\begin{array}{l}\text { more } \\
\text { audit }\end{array}$ & $\begin{array}{l}\text { more } \\
\text { audit }\end{array}$ & $50 / 50$ & $50 / 50$ & $\begin{array}{l}\text { more } \\
\text { audit }\end{array}$ & $50 / 50$ \\
\hline $\begin{array}{l}\text { IAF as } \\
\text { Management } \\
\text { Training Ground }\end{array}$ & Yes & Yes & Yes & No & No & Yes & No & No & Yes \\
\hline $\begin{array}{l}\text { Interviewed } \\
\text { Hierarchy Levels } \\
\text { of the IAF }\end{array}$ & $\begin{array}{l}\text { First } \\
\text { Second } \\
\text { Third } \\
\end{array}$ & $\begin{array}{l}\text { First Second } \\
\text { Third }\end{array}$ & $\begin{array}{l}\text { First } \\
\text { Second }\end{array}$ & $\begin{array}{l}\text { First } \\
\text { Second } \\
\text { Third } \\
\end{array}$ & $\begin{array}{l}\text { First } \\
\text { Second }\end{array}$ & $\begin{array}{l}\text { First Second } \\
\text { Third }\end{array}$ & First Second & First & $\begin{array}{l}\text { First Second } \\
\text { Third }\end{array}$ \\
\hline $\begin{array}{l}\text { Number of } \\
\text { Interviews } \\
\text { Conducted } \\
\end{array}$ & 3 & 3 & 2 & 3 & 2 & 6 & 3 & 1 & 3 \\
\hline Internationality & National & Global & Global & Regional & Global & Multinational & Multinational & Global & National \\
\hline $\begin{array}{l}\text { Profit/ Non- } \\
\text { Profit }\end{array}$ & Non-Profit & Profit & Profit & Profit & Profit & Profit & Profit & Profit & $\begin{array}{l}\text { Non- } \\
\text { Profit }\end{array}$ \\
\hline Listing & No & Yes & Yes & Yes & Yes & Yes & Yes & No & No \\
\hline $\begin{array}{l}\text { Location of } \\
\text { Headquarter }\end{array}$ & Europe & Europe & Europe & Europe & Europe & Europe & Europe & $\begin{array}{c}\text { North } \\
\text { America }\end{array}$ & $\begin{array}{c}\text { North } \\
\text { America }\end{array}$ \\
\hline
\end{tabular}


Table 2. IAF Characteristics for the profiling of best practices

\begin{tabular}{|c|c|c|c|c|c|c|c|c|}
\hline No. & $R Q$ & Item & \multicolumn{6}{|c|}{ Values } \\
\hline 1. & 1 & $\begin{array}{l}\text { IAF Structure compared to } \\
\text { Organizational Structure }\end{array}$ & \multicolumn{3}{|c|}{ not congruent (1) } & \multicolumn{3}{|c|}{ congruent (2) } \\
\hline 2. & 1 & $\begin{array}{l}\text { Objectivity and } \\
\text { Independence }\end{array}$ & \multicolumn{3}{|c|}{ not secured (1) } & \multicolumn{3}{|c|}{ secured (2) } \\
\hline 3. & 1 & Organizational Orientation & $\begin{array}{l}\text { function } \\
\text { (1) }\end{array}$ & region (2) & $\begin{array}{l}\text { more than } \\
\text { one (3) }\end{array}$ & unit (4) & process (5) & market (6) \\
\hline 4. & 2 & Qualification Model & \multicolumn{2}{|c|}{ generalist (1) } & \multicolumn{2}{|c|}{ specialist (2) } & \multicolumn{2}{|c|}{ both (3) } \\
\hline 5. & 2 & Common Ground & \multicolumn{3}{|c|}{ no (1) } & \multicolumn{3}{|c|}{ yes (2) } \\
\hline 6. & 2 & $\begin{array}{l}\text { Number of IAF Hierarchy } \\
\text { Levels }\end{array}$ & 1 & 2 & 3 & 4 & \multicolumn{2}{|c|}{5} \\
\hline 7. & 2 & $\begin{array}{l}\text { Auditors per } 1000 \\
\text { Employees }\end{array}$ & $<0.5(1)$ & $\begin{array}{l}0.5-1.0 \\
(2)\end{array}$ & $\begin{array}{c}1.0-2.5 \\
(3)\end{array}$ & $2.5-5(4)$ & \multicolumn{2}{|c|}{$>5(5)$} \\
\hline 8. & 2 & Audit Planning Loop & $\begin{array}{l}\text { continuo } \\
\text { usly } \\
\text { (1) }\end{array}$ & $\begin{array}{c}\text { half-year } \\
\text { (2) }\end{array}$ & 1 year $(3)$ & 2 year $(4)$ & \multicolumn{2}{|c|}{5 year $(5)$} \\
\hline 9. & 2 & Audit Planning & \multicolumn{3}{|c|}{ not risk-oriented (1) } & \multicolumn{3}{|c|}{ risk-oriented (2) } \\
\hline 10. & 2 & The focus of Audit Activities & \multicolumn{2}{|c|}{ consulting (1) } & \multicolumn{2}{|c|}{ auditing (2) } & \multicolumn{2}{|c|}{ both (3) } \\
\hline 11. & 3 & Reporting to CEO & \multicolumn{3}{|c|}{ indirect (1) } & \multicolumn{3}{|c|}{ direct (2) } \\
\hline 12. & 3 & Reporting to Audited Unit & \multicolumn{3}{|c|}{ indirect (1) } & \multicolumn{3}{|c|}{ direct (2) } \\
\hline 13. & 3 & Reporting to AC & \multicolumn{3}{|c|}{ indirect (1) } & \multicolumn{3}{|c|}{ direct (2) } \\
\hline 14. & 3 & Reporting to External Unit & \multicolumn{3}{|c|}{ indirect (1) } & \multicolumn{3}{|c|}{ direct (2) } \\
\hline 15. & 3 & Number of Control Loops & $0(1)$ & $1(2)$ & $2(3)$ & $3(4)$ & \multicolumn{2}{|c|}{$4(5)$} \\
\hline 16. & 3 & $\begin{array}{l}\text { The intensity of Cooperation } \\
\text { Executive Directors }\end{array}$ & $\begin{array}{l}\text { annually } \\
\text { (1) }\end{array}$ & $\begin{array}{l}\text { more than } \\
\text { once }(2)\end{array}$ & $\begin{array}{l}\text { quarterly } \\
\text { (3) }\end{array}$ & $\begin{array}{l}\text { monthly } \\
(4)\end{array}$ & $\begin{array}{l}\text { continuously } \\
(5)\end{array}$ & $\begin{array}{l}\text { on request } \\
\text { (6) }\end{array}$ \\
\hline 17. & 3 & $\begin{array}{l}\text { Intensity of Cooperation } \\
\text { Audit Committee }\end{array}$ & $\begin{array}{l}\text { annually } \\
\text { (1) }\end{array}$ & $\begin{array}{l}\text { more than } \\
\text { once }(2)\end{array}$ & $\begin{array}{l}\text { quarterly } \\
\text { (3) }\end{array}$ & $\begin{array}{l}\text { monthly } \\
\text { (4) }\end{array}$ & $\begin{array}{c}\text { continuously } \\
(5)\end{array}$ & $\begin{array}{l}\text { on request } \\
\text { (6) }\end{array}$ \\
\hline 18. & 3 & $\begin{array}{l}\text { Intensity of Cooperation } \\
\text { Risk Management }\end{array}$ & $\begin{array}{l}\text { annually } \\
\text { (1) }\end{array}$ & $\begin{array}{l}\text { more than } \\
\text { once }(2)\end{array}$ & $\begin{array}{l}\text { quarterly } \\
\text { (3) }\end{array}$ & $\begin{array}{l}\text { monthly } \\
(4)\end{array}$ & $\begin{array}{c}\text { continuously } \\
(5)\end{array}$ & $\begin{array}{l}\text { on request } \\
(6)\end{array}$ \\
\hline 19. & 3 & $\begin{array}{l}\text { Intensity of Cooperation } \\
\text { Compliance }\end{array}$ & $\begin{array}{l}\text { annually } \\
\text { (1) }\end{array}$ & $\begin{array}{l}\text { more than } \\
\text { once (2) }\end{array}$ & $\begin{array}{l}\text { quarterly } \\
\text { (3) }\end{array}$ & $\begin{array}{l}\text { monthly } \\
(4)\end{array}$ & $\underset{(5)}{\text { continuously }}$ & $\begin{array}{l}\text { on request } \\
(6)\end{array}$ \\
\hline 20. & 3 & $\begin{array}{l}\text { Intensity of Cooperation } \\
\text { Controlling }\end{array}$ & $\begin{array}{l}\text { annually } \\
\text { (1) }\end{array}$ & $\begin{array}{c}\text { more than } \\
\text { once }(2)\end{array}$ & $\begin{array}{l}\text { quarterly } \\
\text { (3) }\end{array}$ & $\begin{array}{l}\text { monthly } \\
(4)\end{array}$ & $\begin{array}{c}\text { continuously } \\
(5)\end{array}$ & $\begin{array}{c}\text { on request } \\
(6)\end{array}$ \\
\hline 21. & 3 & $\begin{array}{l}\text { The intensity of Cooperation } \\
\text { External Auditor }\end{array}$ & $\begin{array}{l}\text { annually } \\
(1)\end{array}$ & $\begin{array}{l}\text { more than } \\
\text { once }(2)\end{array}$ & $\begin{array}{l}\text { quarterly } \\
\text { (3) }\end{array}$ & $\begin{array}{l}\text { monthly } \\
(4)\end{array}$ & $\begin{array}{c}\text { continuously } \\
(5)\end{array}$ & $\begin{array}{l}\text { on request } \\
\text { (6) }\end{array}$ \\
\hline 22. & 3 & $\begin{array}{l}\text { Intensity of Cooperation } \\
\text { Other External }\end{array}$ & $\begin{array}{l}\text { annually } \\
\text { (1) }\end{array}$ & $\begin{array}{l}\text { more than } \\
\text { once }(2)\end{array}$ & $\begin{array}{l}\text { quarterly } \\
\text { (3) }\end{array}$ & $\begin{array}{l}\text { monthly } \\
(4)\end{array}$ & $\begin{array}{l}\text { continuously } \\
(5)\end{array}$ & $\begin{array}{l}\text { on request } \\
\text { (6) }\end{array}$ \\
\hline
\end{tabular}

Table 3. IAF's identified practices and potential benefits

\begin{tabular}{|c|c|}
\hline IAF's Practices & Potential Benefits \\
\hline Simultaneous reporting to all relevant addressees & $\begin{array}{l}\text { Information asymmetries due to sequential reporting are } \\
\text { avoided }\end{array}$ \\
\hline $\begin{array}{l}\text { Group mail communication for relevant findings, which are } \\
\text { essential for the entire organization }\end{array}$ & $\begin{array}{l}\text { Communicating potential risks and inefficiencies, decreases } \\
\text { the probability of a negative event }\end{array}$ \\
\hline $\begin{array}{l}\text { Audit reports are designed in a standardized lay-out } \\
\text { containing a management summary and a"quick evaluation" }\end{array}$ & $\begin{array}{l}\text { Addressees view the internal audit reports and then decide if a } \\
\text { detailed analysis is necessary }\end{array}$ \\
\hline $\begin{array}{l}\text { Job rotation, especially after M\&A-transactions or the } \\
\text { implementation of international audit units }\end{array}$ & $\begin{array}{l}\text { A common ground, consistent code of ethics, routines, and } \\
\text { processes are implemented within IAF }\end{array}$ \\
\hline Regular meetings of all internal audit member & $\begin{array}{l}\text { A common ground, consistent code of ethics, routines, and } \\
\text { processes are implemented within IAF; Meetings facilitate } \\
\text { communication between internal audit members }\end{array}$ \\
\hline $\begin{array}{l}\text { Close coordination between IAF and other gover- } \\
\text { nance bodies }\end{array}$ & $\begin{array}{l}\text { Exchange of information in order to improve the daily internal } \\
\text { audit business }\end{array}$ \\
\hline Use of the TLoD-model framework & $\begin{array}{l}\text { IAF builds the last line of defense, which yields an increase in } \\
\text { the acceptance of the IAF and stabilizes its superior position }\end{array}$ \\
\hline Positioning of the different governance bodies at one location & $\begin{array}{l}\text { Improved communication; Creation of a } \\
\text { understanding of "good corporate governance" }\end{array}$ \\
\hline $\begin{array}{l}\text { Interfaces between IAF and other governance bodies are clearly } \\
\text { defined }\end{array}$ & $\begin{array}{llll}\begin{array}{l}\text { Concentration } \\
\text { duplications }\end{array} & \text { on } & \text { core-competencies; } & \text { Avoidance } \\
\end{array}$ \\
\hline $\begin{array}{l}\text { Ad-hoc meetings with the responsible members of the board of } \\
\text { directors are possible }\end{array}$ & $\begin{array}{l}\text { Ad-hoc meetings facilitates prompt discussion and } \\
\text { hence the solution of problems }\end{array}$ \\
\hline Ideal qualification level of the auditors & $\begin{array}{l}\text { Audits take place on a par with the audited units; } \\
\text { Auditors are able to close cultural gaps }\end{array}$ \\
\hline Joint audit teams & $\begin{array}{l}\text { Ideal composition of auditors regarding their expertise, social } \\
\text { and cultural qualification; Continuous exchange of knowledge } \\
\text { between the auditors; Creation of a common ground }\end{array}$ \\
\hline $\begin{array}{l}\text { IAF takes care for training and qualifying young high- } \\
\text { potentials }\end{array}$ & $\begin{array}{l}\text { High-potentials need to learn about organizational processes } \\
\text { in order to prepare them for future careers }\end{array}$ \\
\hline
\end{tabular}




\section{APPENDIX B}

Table 4. Results of IAF profiling

\begin{tabular}{|c|c|c|c|}
\hline No. & $R Q$ & Item & Summary of the Results \\
\hline 1. & 1 & IAF Structure compared to Organizational Structure & Identical results: Congruent Structure 100\% \\
\hline 2. & 1 & Objectivity and Independence & Identical results: Secured 100\% \\
\hline 3. & 1 & Organizational Orientation & No identical results \\
\hline 4. & 2 & Qualification Model & No identical results \\
\hline 5. & 2 & Common Ground & Identical results: Common Ground Structure 100\% \\
\hline 6. & 2 & Number of IAF Hierarchy Levels & No identical results \\
\hline 7. & 2 & Auditors per 1000 Employees & No identical results \\
\hline 8. & 2 & Audit Planning Loop & No identical results \\
\hline 9. & 2 & Audit Planning & No identical results \\
\hline 10. & 2 & The focus of Audit Activities & No identical results \\
\hline 11. & 3 & Reporting to CEO & Identical results: Direct 100\% \\
\hline 12. & 3 & Reporting to Audited Unit & Identical results: Direct 100\% \\
\hline 13. & 3 & Reporting to AC & No identical results \\
\hline 14. & 3 & Reporting to External Unit & No identical results \\
\hline 15. & 3 & Number of Control Loops & No identical results \\
\hline 16. & 3 & The intensity of Cooperation Executive Directors & No identical results \\
\hline 17. & 3 & Intensity of Cooperation Audit Committee & No identical results \\
\hline 18. & 3 & Intensity of Cooperation Risk Management & No identical results \\
\hline 19. & 3 & Intensity of Cooperation Compliance & No identical results \\
\hline 20. & 3 & Intensity of Cooperation Controlling & No identical results \\
\hline 21. & 3 & The intensity of Cooperation External Auditor & No identical results \\
\hline 22. & 3 & Intensity of Cooperation Other External & No identical results \\
\hline
\end{tabular}


Figure 1. Attributes of participants' IAF

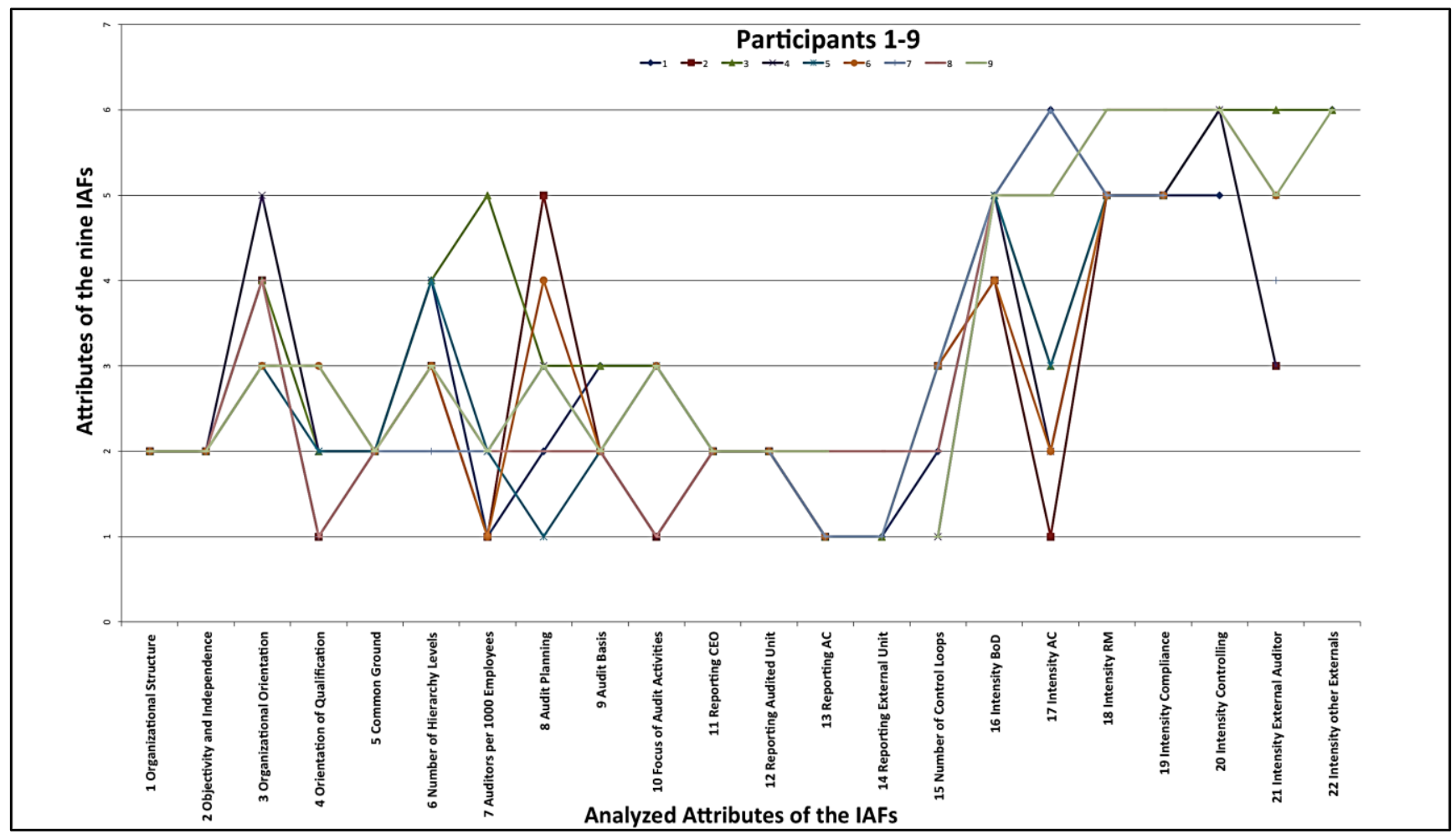

